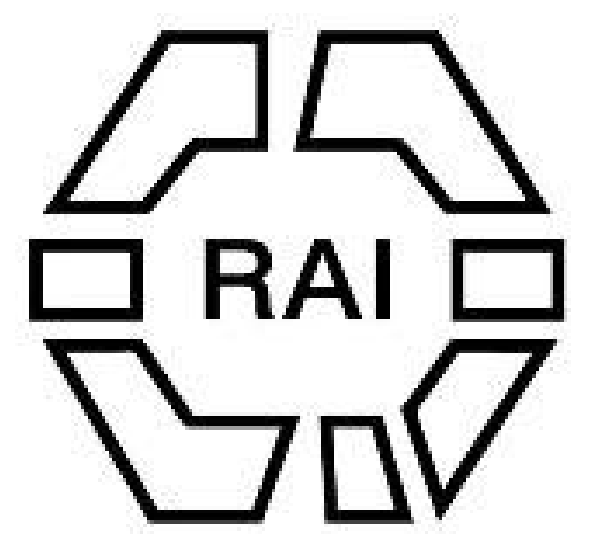

\title{
WILEY
}

\section{Mothers and Children at Laguna.}

\section{Author(s): Elsie Clews Parsons}

Source: Man, Vol. 19 (Mar., 1919), pp. 34-38

Published by: Royal Anthropological Institute of Great Britain and Ireland

Stable URL: http://www.jstor.org/stable/2839943

Accessed: 24-06-2016 21:06 UTC

Your use of the JSTOR archive indicates your acceptance of the Terms \& Conditions of Use, available at

http://about.jstor.org/terms

JSTOR is a not-for-profit service that helps scholars, researchers, and students discover, use, and build upon a wide range of content in a trusted digital archive. We use information technology and tools to increase productivity and facilitate new forms of scholarship. For more information about JSTOR, please contact support@jstor.org.

Royal Anthropological Institute of Great Britain and Ireland, Wiley are collaborating with JSTOR to digitize, preserve and extend access to Man 
objects and is the only one of its kind. The dimensions are $8.3 \mathrm{~cm}$. by $4.3 \mathrm{~cm}$. The hollows show as pale lines, like most Mexican carvings. There are only four digits on each extremity. The officials of the National Museum kindly permitted me to make all these drawings during a recent visit.

The frog is intimately associated with the coming of rain in Mexico (also in Peru), and the specimen has hands uplifted in a praying attitude whilst the tongue hangs out as if with thirst. It is a fact that the frogs croak at the end of the long dry season when every one is looking at the sky and hoping for a shower, and cattle in the fields low, "calling the rain." Mexicans say the frogs pray for rain, and in Yucatan the croaking of the large frog is a sure sign of rain within three days. Their contented thankful chant afterwards sounds quite differently.

A. C. BRETON.

\section{New Mexico: Folklore.}

Parsons.

\section{Mothers and Children at Laguna. By Elsie Clews Parsons.}

Wana's baby was two weeks old on my last (1918) visit to Laguna, and 10 as the baby lay in her belooded board cradle on the floor or, still in her compartment, on the lap of her mother or her great-aunt, our talk led naturally from her and her short experience to ways with babies in general. Like other Pueblo Indian babies, she liad been taken outdoors and presented to the gods. On the fourth morning of her life, before sunrise, one of thè two surviving medicine-men of Laguna, the shiwanna (thunder) cheani came to the house and laid out on the floor of the upper room of the two-storied house his altar paraphernalia. Wana made for me the following diagram of the altar :-

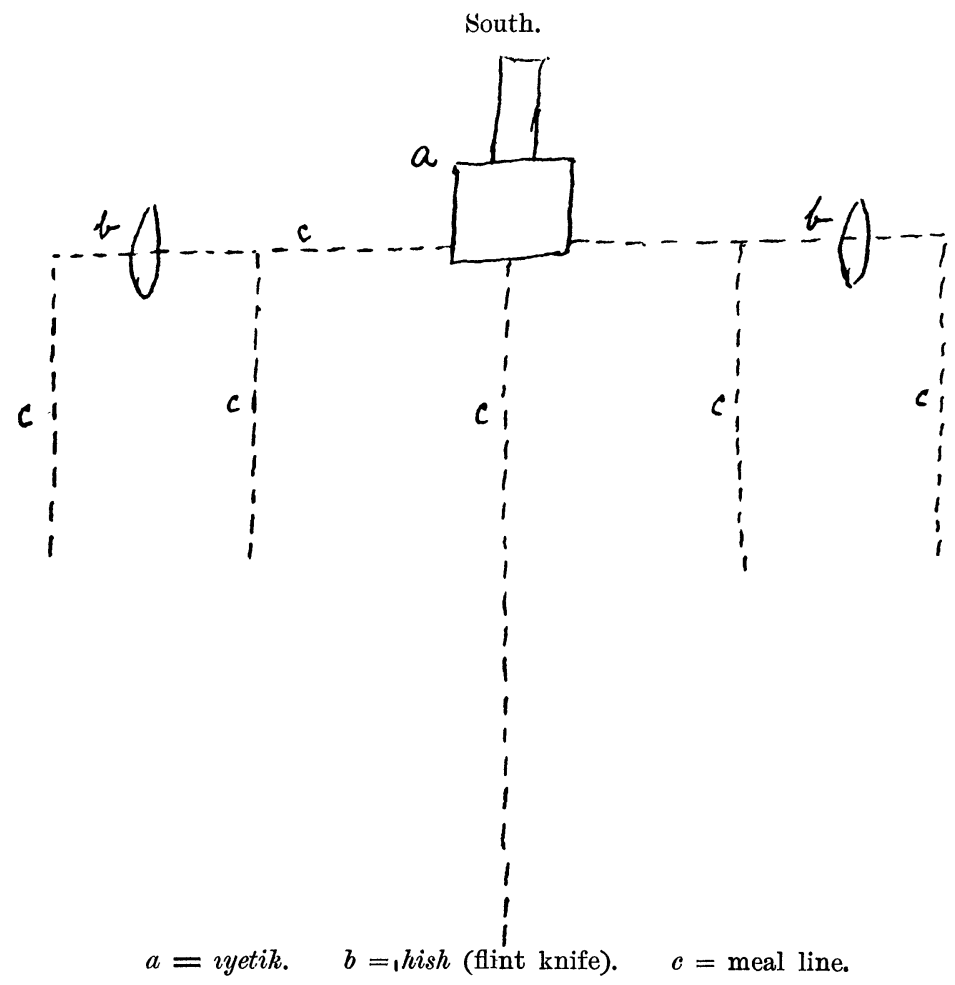

The iyetik is a fetich or symbol of the deity within the earth, a deity who is to the Keresans a source of being and the most revered of all their supernaturals, naiya 
(mother) iyetiku. The symbolic iyetik is an ear of corn wrapped with unspun cotton and set in a little buckskin cap. When set out on an altar-the only time it is exposed-it is dressed with feathers and encircled with a string of precious beadsturquoise and white shell beads, together with olivella or abalone shells. On either side of the iyetik in our diagrammatic altar is a flint knife. The flint knives serve in this case, I surmise, as in other cases of ceremonial usage, as a guard to the iyetik or altar against witches or evil spirits.* 'The central line of meal is a roadway for the kopishtaiya, the benevolent supernaturals, probably in this case more particularly for naiya iyetik, to come in by. Usually on altars the meal road leads from the east, the altar facing the east. I could not learn why in this instance the characteristic position was changed. In myth, to be sure, naiya iyetik lives at shipopolima (in the north).

In the diagram of the altar a medicine-bowl should have been represented, as from it, out of his shell cup, $\uparrow$ the shiwanna cheani gave Wana a drink, and from it with his eagle feathers he also asperged mother and child, two little rites of constant occurrence in Pueblo Indian ceremonials. According to one informant there should also be a crook stick on the altar, as with it the cheani would sprinkle meal on the infant.

After the preliminaries at the altar, the order of which I could get with no certainty, the cheani took mother and child out on the southern terrace of their house. With them went Wana's aunt (her mother's sister; her mother is dead), Getsitsa, the head of Wana's household, $\S$ an old lady whom, in accordance with Keresan kinship terminology, Wana calls naiya, mother. Out on the terrace Gestitsa, facing the east, said this prayer\|:-

$$
\text { shauau naiya osach waii gaiutse waniumaš she shkutsipa }
$$

Now mother [iyetik] sun this morning I am going out. I want

samaak nitunigunishe Tashgama sukiutsi eme shkutsipa nitunigunishe du my daughter grow up daily all the time this want grow up this hiname osach hano dieshe Ges.**

myself sun clan thus.

"Now Mother [iyetik understood], Sun, this morning I am going out. I want my daughter [the infant] to grow day by day. Thus all the time I want her to grow. I myself am of the Sun clan. I am Ges."

After sprinkling meal on the ground and making four times a circular gesture with both hands raised, palms upward, to the East and drawn back, a ritualistic invitation to the kopishtaiya, and after breathing on the infant, $\dagger \dagger$ the cheani prayed as follows:-

towiki naiya naishdiya toheme tauwa nawigesineshe Here give mother [iyetik] father [Sun] that is all good relationship

* Spear points figure among the Sia in what appears to be a rite of exorcism after a birth. Stevenson, M.C.: "The Sia," p. 139, XI (1889-90).-Ann. Rep. Bur. Bthnol.

$\dagger$ Shells are used for medicine-water among the Sia, likewise among the Zuñi.

¥ The infant's paternal grandmother is unknown, the father being unknown; but, in any circumstance, I am told, it is the maternal, not the paternal grandmother who attends the presentation rite.

$\S$ The other members are Wana's father and Wana's three-year-old daughter.

|| Another informant, describing the presentation rite in general, asserted that the grandmother would not say any prayer.

I Also translated "grow strong." Another informant insisted that this word should be translated "to know about it."

** In other connections her name was always given as Getsitsa.

†† In Pueblo ceremonials sacrosanct things are commonly breathed upon, and impersonators of the gods, at Zuñi at least, breathe upon the layman. According to Stevenson, the Sia infant is breathed on. ("The Sia," p. 141.) 
tsityu tsitawa hanonatakonishe emitoa shkutsipa naiya naishdiya towik* of value goodness people multiplying this way want mother father take iani cheowa taame shkutsipa.

road take this ask want.

"Here I give you the child, Mother iyetik, Father Sun. 'That is all. Good and valuable relationship (i.e., of kin and clan), goodness, increase of people. Such I want. Mother iyetik, Father Sun, take the road [of the child's life]. This I ask and want."

Two ceremonial requirements in connection with or subsequent to the rite should be mentioned. Before the rite the mother's hair has been washed-a hair wash is commonly required before Pueblo Indian ceremonials-and before the rite and after, for twelve days after the birth, the woman is expected to be continent. In case of violation (cheachsi) she would dry up (tsipanito), i.e., die, $\dagger$ unless she were given a purge by the medicineman.

In this presentation rite there was no reference to naming the infant, and when I made the acquaintance of the baby she had not as yet been given any name. How she would get her Indian name I did not hear from Wana, $\ddagger$ but there was talk of how in course of time she would be given an "American" name in baptism at the Catbolic church. Water would be put to her head and salt to her lips and the Spanish god-

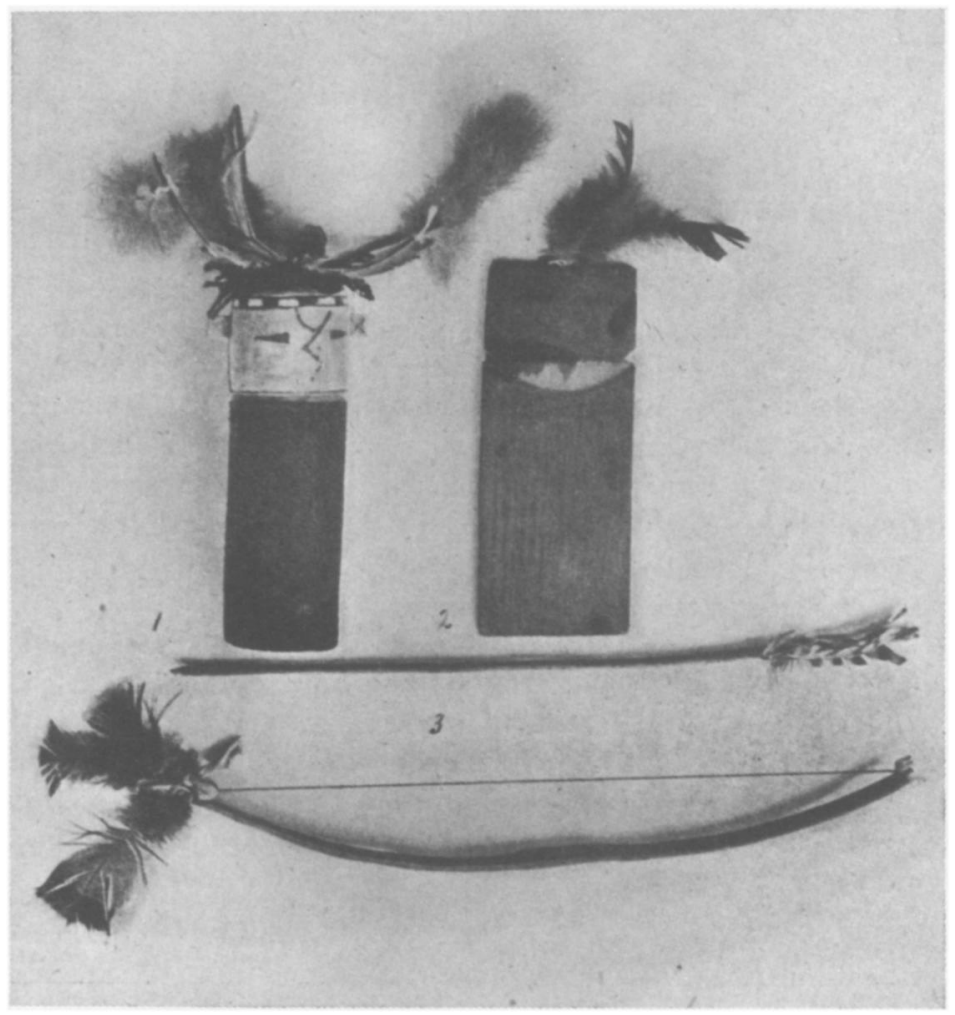
parent institution would be entered into. Every Christmas thereafter her godmother, her mother's comadre, would give her a present-and her mother would give a return present to her godmother.

Laguna children, like other Pueblo Indian children, receive other presents, presents of a more distinctively native character. While a ceremonial by masked dancers or katsena is under way, parents will ask one of the dancers, perhaps a

* An unfamiliar word. The cheani have a peculiar vocabulary.

$\dagger C p$. Parsons, E.C. : "Zuñi Death Beliefs and Practices."-American Anthropologist. XVIII, (1916), 246.

I According to other informants names are suggested by the medicine-man, but not at the presentation rite. (Cp. "The Sia," p. 141.) 
kinsman, to make a bow and arrow or an auwak (a baby) for their child-bow and arrow for a boy, auwak for a girl. The parent supplies the materials, and in using them the dancer says a prayer for the good of the child. As among the Zuñi or the Hopi the dolls represent the katsena themselves. Fig. 1 represents a male impersonator called nawish. It was made in the autumn of 1917, during the yakohanna or corn dance, and until my visit a few months later it had been standing on a shelf of the child's house. Fig. 2 represents a kuchinninaku or girl katsena. It was given me by the little girl who had been playing with it. Fig. 3 represents the ishtua (arrow, bow understood) given by the katsena to boys, to boys past infancy; to baby boys such a gift, it is believed, would bring with it life-long bad temper.

By an elderly informant, comadre by the way in eight families, was sung for me the two following lullabies :-

hawi hawi hawi-i amu maku shuwiminatse uwitsimikia aihamakoshewi Who who who dear be quiet turquoise baby board on hush showaini ni e a shuwiminatse uwitsimikia.

take care turquoise baby board on.

" There, there, there,

Dear be quiet,

On a turquoise* baby board

Hush, take care

On a turquoise baby board."

hawi hawi hawi kuchinninaku tsekuma shutsaiawita tsekuma shunashgatsita amu Who who who girl why angry why captious, cross dear kuchinninaku tuwa tuwa chikutuemetse tuwa tuwa gaitayadyama shannakura kwie girl here here wild roses here here moonlight flowers give chukwoyà amu. take dear.

\author{
“' There, there, there \\ Girl, why are you angry \\ Why are you captious, dear girl? \\ Here, here are wild roses \\ Here, here is moonlight \\ The flowers, take them, dear."
}

My singer was a knowing and communicative acquaintance. Unlike the younger generation at Laguna, she was interested in past or passing customs. Various beliefs and practices in connection with mothers and children of which she told seem worth recording. If a pregnant woman sits with her back to the sun the placenta will "stick." Hence when the placenta is retarded someone present is apt to say, "Perhaps she sat with her back to the sun and the sun baked her back." Twins may be due to witcheraft. A witch will make two balls of earth wet by urine and roll the balls in the direction of the woman who has urinated. Hence urinating in the road is disapproved of. $\dagger$ If a baby is born with teeth it is a sign that before his birth his mother has looked at a snake. Parental indiscretions of this kind are the stock explanation of congenital deformities at Zuñi.ł My Laguna informant explained only one case in this way, the case of a child born with a piece out of

* The board was painted turquoise.

+ Nor should water lying in the road be drunk. It would cause tuberculosis- "there are so " many travellers in a road."

¥ Parsons, E. C. : "Zuñi Conception and Pregnancy Beliefs."-Proc. XIX, International Congress of Americanists, pp. 382-3. Washington, 1917. 
his ear, the explanation being that his father had gone out shooting during the pregnancy.

Soon after the birth, perhaps even the first day, ashes will be rubbed on the child, " rubbed in the form of a cross on forehead, on chin, and on legs-witches dislike ashes. After hearing about this witchcraft prophylaxis I asked Wana and Getsitsa if the baby had been rubbed yet with ashes. "No," said Wana, "but naiya " has been thinking about it." The next mórning they told me the ashes had been rubbed on-rubbed on the forehead, as I saw when they showed me the baby, just as on Zuñi babies. The ashes were not rubbed on in the form of a cross, nor were they rubbed anywhere else on the body.

There is, or rather was, said my elderly informant, a prejudice at Laguna against clipping a boy's hair, a prejudice probably characteristic, I may add, of all the Pueblo Indians. Once a godchild who was out herding sheep had lice in his hair, so "they" cut it short. His mother felt greatly distressed, and exclaimed to her comadre, "They scattered my blood and my health to the four winds!"

Formerly at Laguna, in the days when there were no tables and the household formed a circle around the bowls on the floor, each kneeling on the left knee, none would drink until eating was accomplished. After the meal a senior might touch the breast of a child and say, "Now if all your food has gone down you may drink." Then or at any other time when a senior asked a child to bring him or her-a drink the child was expected to stand with arms folded until the senior said, Shetunii, "May you grow tall!" Tauwa (good, i.e., "thanks") responded the junior.

ELSIE CLEWS PARSONS.

\section{British New Guinea.}

Muguru at Torobina, Bamu ,River. By L. A. Flint.

Flint.

When visiting the village of Torobina, on Damera Island, in the estuary of the Bamu, I noticed that a new $d u b u \dagger$ was just completed, and that a muguru was to take place in the village that night. After considerable persuasion the natives allowed me and a couple of the police to view the ceremony, and I went there at nightfall.

The interior of the building was decorated with crotons and nipa palm leaves to about 40 to 50 feet from one end. The men of the village sat beneath these decorations, a number of whom sounded the kibi, $\neq$ whilst others kept up a song. for about an hour and a half. A native, who was evidently the master of the ceremonies for the night, then went to the other end of the $d u b u$, and the other men moved to the wall and sat in a line. After waiting for about ten minutes twenty-one nude women, each carrying a torch, marched two deep up the building to where the men were sitting. As the women approached, the men began to sing " $\mathrm{Ob}, \mathrm{Oh}$ " for a couple of minutes; when they stopped singing the men jumped up and each claimed a woman.

Immediately all the fires were covered up and all was in semi-darkness, but I saw the natives copulating, and the young children who were present also witnessed it. After fifteen minutes had elapsed a kibi was sounded and the fires brightened up; the women returned to the far end of the $d u b u$, and the singing recommenced

* Cp. "The Sia," p. 141.

$\uparrow$ The $d u b u$ is evidently a "long house" presumably equivalent to the $d u b u$ daima of the Kerewa folk (A. C. Haddon, MAN, 1918, 99).

$\ddagger$ According to E. W. P. Chinnery (MAN, 1917, 55), kipi is the name for a wooden trumpet in Northern Britisb New Guinea; if the $k i b i$ is a similar instrument, it constitutes a new récord cf. A. C. Haddon, MAN, 1917, 56). Probably it is a shell trumpet. 